\title{
R EVIEW S
}

\section{NEW WORLDS EMERGING.}

By Earl Parker Hanson. New York: Duell, Sloan and Pearce, 1949. $8 \frac{1}{2} \times 5 \frac{1}{2}$ inches; xix + 386 pages; end-paper map. \$3.50.

For a quarter of a century the author lived and worked in Chile, Iceland, Canada, the Amazon Basin, the Northern Andes, Puerto Rico and Liberia. As an engineer and planner he learned his geography in the field and now as Chairman of the Department of Geography at the University of Delaware he finds much to disagree with in the work of academic geographers. There is much a specialist can find to disagree with in his interpretations and opinions, and his excursions into the fields of political economy and economics, population problems, and the management of resources both material and human.

The strength of the book lies in the fact that he has written about areas which he knows at first hand. The treatment is not claimed to be comprehensive, but he has singled out some of the most significant problems and developments in these areas, as well as using them as illustrations and examples of the central theme of the book. This theme is that the energies of the men, capital and technology of North America are not now being directed into the temperate areas of the world but into the Arctic and tropics where new worlds are emerging. Great emphasis is placed on the need for changes in racial concepts and in the attitude to undeveloped peoples, whom he considers to be as important an economic frontier as undeveloped land and material resources.

He traces through history the widespread misconception that the tropics and the Arctic are both impossible as permanent homes for white men, and that no real civilization can arise or thrive there. In his discussion of the Arctic in this respect, he has been influenced by the work of Stefansson.

The author has done most of his work in the deserts and tropics and the Arctic section of the book will be disappoint- ing to the Arctic specialist in that it contributes little that is new in substance or in point of view. It is confined to four areas, namely Iceland, the Polar Sea, the Soviet Arctic and Alaska.

The historical development of Iceland is traced in outline, through the colonial phase of economic and social poverty, which was interpreted by many to show that they were unfit for self-rule, lacking in moral fibre and a sense of responsibility, and the gradual political and economic emancipation leading to the present state, which, "functions so well that their nationals cannot be persuaded to emigrate."

The history of the exploration of the Polar Sea is described briefly, with particular attention to the work of Stefansson and Wilkins who have done so much to shatter the old illusion of the desolate and lifeless Arctic. This illusion persisted in spite of the fact that the necessary data had been observed and recorded for half a century, but had been ignored because it did not fit the pattern of established thought.

The Soviet Arctic and Alaska are briefly reviewed. The emphasis in the former case is on the variety of fields in which progress has been made to establish permanent populations in areas which would earlier have been dismissed as impossible for civilian communities. In the latter case the author confines himself mainly to the varying schemes and plans for the development of Alaska by the United States government.

I.B.

GR $\emptyset$ NLAND (Greenland).

By Jette Bang. Copenhagen: Det Gronlandske Selskab (The Greenland Society), 1941.101 $x 9$ incbes; 187 pages.

GR $\emptyset$ NLAND. Copenbagen:The Greenland Administration, 1947. $13 \times 10^{\frac{1}{2}}$ inches; 96 pages.

These two books of Greenland photographs are remarkably good and yet so very different. 